\title{
ミスト冷却における焼結多孔体面の伝熱促進効果*
}

\author{
小坂 暁夫 ${ }^{* 1}$, 宮下 将志 ${ }^{* 2}$, 多田 幸生 ${ }^{* 3}$, 㴰本 昭 $^{* 4}$
}

\section{Effectiveness of Sintered Porous Surface for Mist Cooling Heat Transfer}

\author{
Akio KOSAKA ${ }^{* 1}$, Masashi MIYASHITA, Yukio TADA and Akira TAKIMOTO \\ ${ }^{* 1}$ Grad. School of Science and Engineering for Research, \\ Toyama University, Gofuku 3190, Toyama, 930-8555 Japan
}

This study experimentally examined evaporation of the single droplet deposited on the heated surface where copper fine powders had been sintered. A sintered layer, which was made by Spark Plasma Sintering, ranges in porosity from 0.19 to 0.55 , and in a thickness from 70 to $600 \mu \mathrm{m}$. Porous surfaces expanded the contact area of deposited droplet, and hence a contact angle was reduced as compared to non-porous surfaces. This area was also enlarged by an increase in pre-impact Weber number. A droplet being placed on the porous surface that had specific porosity, a wetted zone due to permeation instantly surrounded the droplet. Under a constant surface temperature, droplet lifetimes on the porous surfaces where the wetted zone did not appear shortened with increasing Weber number, since enlargement of the contact area and/or a droplet breakup occurs on the surface. For the surface where the zone largely formed, droplet lifetimes were almost independent of Weber number because of the larger evaporation interface that had grown by wicking. Mostly, the porous surfaces enhanced droplet evaporation in low temperature range.

Key Words : Mist Cooling, Heat Transfer Enhancement, Sintered Porous Surface, Droplet, Evaporation

\section{1. 緒言}

噴霧液滴群を高温面に衝突・蒸発させるミスト冷却は, 壁面温度および熱流束の制御性や任意環境一の適用性 などに優れた熱除去技術の一つである，宇宙往還機の排熱システム（HSD），パワートランジスター，レーザー ダイオードなどの半導体素子冷却など多岐にわたり応用されている. 近年では，より高熱流束の除去やより均一 な温度制御への対応を要求される(1)など, さらなる技術開発が望まれている.

ミスト冷却は, 加熱面の過熱度と噴霧質量速度を主パラメーターとした蒸発・沸騰伝熱を基本に, 低噴霧量で 高熱流束を除去する，すなわち熱伝達の高効率化を狙うところにある。これには，加熱面上により少ない噴霧量

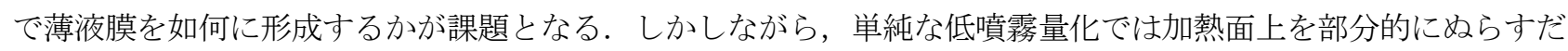
けであり, また, 熱伝達については液滴性状や被冷却物体の性状などの二次的なパラメーターの検討も必要とな ってくる.

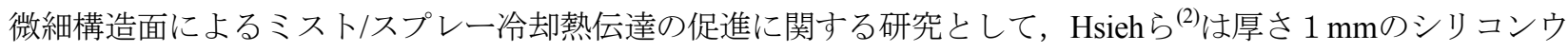

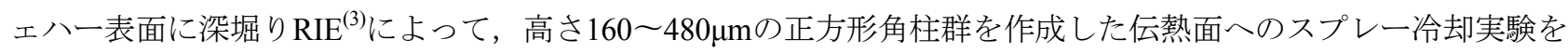
行い, まず単一液滴蒸発実験から, 微細構造面の蒸発促進効果を確認し, スプレー冷却時での効果を予測した. その上で，スプレー冷却実験で，熱伝達特性が伝熱面上でのぬれ様相で 4 つ分類できることを示し，ぬれが部 分的となる温度域において, 伝熱促進されることを示している. 彼らは, この促進効果をより高い熱流束まで, 構造内の毛管力による液膜の拡張と保持によるものと言及しているが，実験方法から推測すれば，単に後者によ

* 原稿受付 2011 年 6 月 20 日

*1 正員, 富山大学大学院（广930-8555 富山県富山市五福 3190）

${ }^{* 2}$ Hitz (日立造船 (株) )

*3 正員, 金沢大学

${ }^{* 4}$ 正員, フェロー, 金沢大学

E-mail:kosaka@eng.u-toyama.ac.jp 
る効果と考えるのが妥当と言える. Silkら ${ }^{(4)}$ も, ほぼ同様な実験系で, 微細構造面の促進効果について追究し, 非 沸騰域, 核沸騰域およびCHF点のいずれも促進することなど実験的に明らかにしている. しかしながら, 彼らが 実験した余剩液 (未蒸発液) が多くなる噴霧量では, 微細構造はいわゆるキャビティとして作用すると考えられ, 核沸騰の促進を狙った構造と寸るべきであろう. Sodtkeら ${ }^{(5)}$ は, ピラミッド型の微細構造面（最小でH75 $\times$ W $150 \mu \mathrm{m} ）$ を用いてスプレー冷却実験を行い，その伝熱促進効果について明らかにした．すなわち，近赤外線カメラを用い た伝熱面の観察から, 微細構造がいわゆる三相境界線長さを増加させ, 結果, 薄液膜蒸発が促進するためと言及 している. 単一液滴列による実験として, Shenら ${ }^{(6)}$ はシリコンナノ構造面（多孔体）を用いた滴下蒸発実験から, 熱的, 流力的過渡現象の測定を行い, ナノ構造面上での液滴の平衡接触角が大きくなることなどを明らかにして いる. 高効率ミスト/スプレー泠却には, まずは単一液滴の蒸発促進が基本であるとする本研究の立場から, Hsieh らによる検討が有益と考えるが，微細構造を有する固体面には，接触径の拡大のほか，いわゆる浸透によるぬれ 広がりが生ずることがある(7) (9)．著者らは、この浸透によるぬれが，著しい蒸発促進効果を示すことを報告(10)(11) しており，この点においていずれの研究も検討が不十分といえる.

著者らは, 以上の観点からミスト冷却の高効率化におよぼす被冷却物体の影響の追究を目的に, これまで(10), 一方向凝固合金の凝固組織に着目し，その加熱表面のみを腐食処理することによって得られる微細構造面を製作 し，これによる (単一) 液滴の蒸発実験により, この伝熱面での蒸発促進効果を明らかにした. しかし，一方向 凝固合金の利用は, るつぼの大きさによって伝熱面寸法が制限されることや構造的な強度など害用性には乏しい. そこで, 本研究では, 実用的な観点から, 製作が容易でかつ任意の構造の製作が可能な方法として, 金属微粉末 を焼結接合することで得られる焼結多孔体に着目した。具体的には, 焼結多孔体面に単一滴を衝突させ, その液 滴浸透および蒸発様相の観察から, ミスト泠却伝熱における有効性について追究したものである.

\begin{tabular}{|c|c|c|}
\hline$D$ & : & 液滴径 $[\mathrm{m}] （ \equiv \sqrt[3]{6 V / \pi})$ \\
\hline$D_{p}$ & : & 銅微粉末径 $[\mu \mathrm{m}]$ \\
\hline$d$ & : & 直径 [m] \\
\hline$H$ & : & 腐食深さ ${ }^{(10)} \quad[\mu \mathrm{m}]$ \\
\hline$h$ & : & 液滴高さ [m] \\
\hline$g$ & : & 重力加速度 $\left[\mathrm{m} / \mathrm{sec}^{2}\right]$ \\
\hline$n$ & : & べき乗数（実験定数） \\
\hline$(r \cos \theta)_{\mathrm{eff}}$ & : & 供試構造面の見かけの毛管半径 $[\mathrm{m}]$ \\
\hline$R$ & : & 浸透液の広がり半径 $[\mathrm{m}]$ \\
\hline$S$ & : & 全蒸発界面積 [m²] \\
\hline$S_{d}$ & : & 液滴の界面積 $\quad\left[\mathrm{m}^{2}\right]$ \\
\hline$S_{p}$ & : & 浸透液の界面積 $\left[\mathrm{m}^{2}\right]$ \\
\hline$S_{d}^{*}$ & : & 液滴部の分率 $\left(\equiv S_{d} / S\right)$ \\
\hline$S_{p}^{*}$ & : & 浸透液部の分率 $\left(1-S_{d}{ }^{*}\right)$ \\
\hline$T$ & : & 温度 $\quad\left[{ }^{\circ} \mathrm{C}\right]$ \\
\hline$t$ & : & 時間 [sec] \\
\hline$t^{*}$ & : & 無次元時間 $\left(\equiv t / \tau_{\text {life }}\right)$ \\
\hline$U_{d}$ & : & 液滴衝突速度 $[\mathrm{m} / \mathrm{sec}](\equiv \sqrt{2 g Z})$ \\
\hline V & : & 液滴体積 $\left[\mathrm{m}^{3}\right]$ \\
\hline$W e$ & : & ウェーバー数 $\left(\equiv \rho_{l} U_{d} D^{2} / \sigma\right)$ \\
\hline$Z$ & : & 液滴の落下高さ $[\mathrm{m}]$ \\
\hline$\delta$ & : & 焼結層厚さ [m] \\
\hline$\varepsilon$ & : & 気孔率 \\
\hline$\mu$ & : & 粘性係数 $[\mathrm{Pa} \bullet \mathrm{sec}]$ \\
\hline
\end{tabular}




\begin{tabular}{|c|c|c|}
\hline$\theta$ & : & 接触角 $\left[{ }^{\circ}\right]$ \\
\hline$\rho$ & : & 密度 $\quad\left[\mathrm{kg} / \mathrm{m}^{3}\right]$ \\
\hline$\sigma$ & 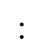 & 表面張力 $[\mathrm{N} / \mathrm{m}]$ \\
\hline$\tau_{\text {life }}$ & : & 液滴寿命［sec] \\
\hline
\end{tabular}

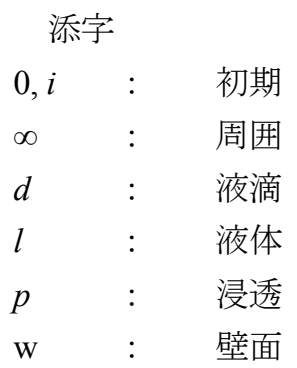

Table 1 Physical properties of the test surface used.

\begin{tabular}{ccccc}
\hline Test sample & $\begin{array}{c}\text { Prosity of } \\
\text { porous layer } \\
\varepsilon\end{array}$ & $\begin{array}{c}\text { Mean diameter of } \\
\text { copper fine particles } \\
D_{p}(\mu \mathrm{m})\end{array}$ & $\begin{array}{c}\text { Thickness of } \\
\text { porous layer } \\
\delta(\mu \mathrm{m})\end{array}$ & $\begin{array}{c}\text { Expansion of } \\
\text { wetted area }\end{array}$ \\
\hline (i) & 0.37 & 53 & 70 & 0 \\
(ii) & 0.55 & 53 & 80 & 0 \\
( iii) & 0.19 & 100 & 600 & \\
\hline
\end{tabular}

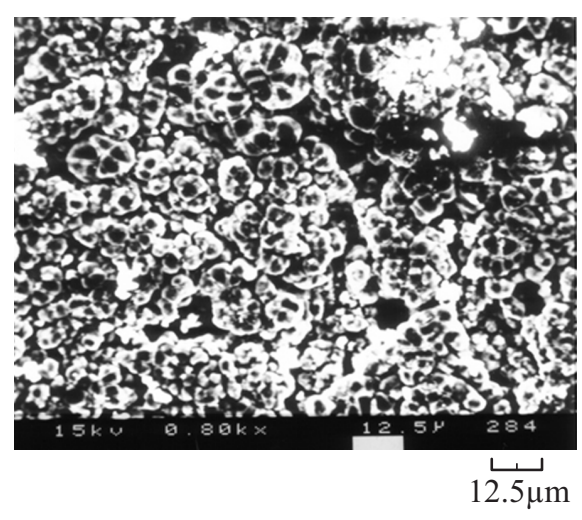

(a)

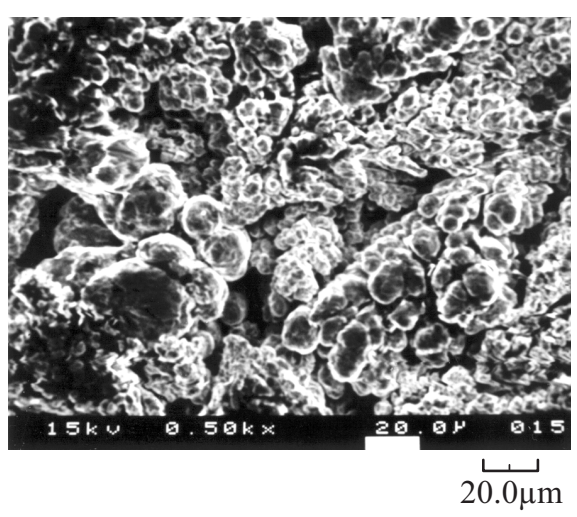

(b)

Fig. 1 Sintered porous surface produced by SPS: (a) $D_{p}=53 \mu \mathrm{m}, \varepsilon=0.37$, (b) $D_{p}=100 \mu \mathrm{m}, \varepsilon=0.19$.

\section{3. 供試伝熱面}

供試伝熱面は，平均粒径（53 と 100 $\mu \mathrm{m} ）$ の純銅製微粉末を放電プラズマ焼結法（SPS）によって，適切な，パ ルス電圧，電流，焼結温度，加圧力，焼結保持時間で焼結接合した直径 $18 \mathrm{~mm}$ ，多孔層厚さ $70 \sim 600 \mu \mathrm{m}$ ，気孔率 0.19 0.55 の多孔体(層)を有する多孔体面を製作したものである. 伝熱面表面の一例を SEM 写真で図 1 に示寸. 本実験では伝熱面として，液体浸透によりぬれが伝熱面上に広がるものと，浸透は多孔層内部のみでぬれは伝熱 面上に広がらない， 2 種類を用意した。さらに前者では，多孔層厚さをほぼ同程度とし，気孔率を変えたものを 作製した，供試した多孔層の諸元を表 1 に示寸，なお，多孔体の有効熱伝導率については，Maxwell の式 ${ }^{(12)} て ゙$ 概 算したところ， $70 \mu \mathrm{m}$ で $211 \mathrm{~W} / \mathrm{m}-\mathrm{K} ， 80 \mu \mathrm{m}$ で $136 \mathrm{~W} / \mathrm{m}-\mathrm{K} ， 600 \mu \mathrm{m}$ では $294 \mathrm{~W} / \mathrm{m}-\mathrm{K}$ である. 


\section{4. 実験装置概要および方法}

実験装置は，既報 ${ }^{(10)}$ とほぼ同様であるが，液滴の供給方法を変えている. 図 2 に示寸，チュービングポンプと 分岐弁とによってある一定流量を確保し，吐き出し側の電磁弁を開閉させることによって，液滴衝突速度を 1.3 〜3.3m/s の範囲で任意に設定した. なお，ノズルは，23G（ゲージ）の注射針の先端を直角に切断して使用した.

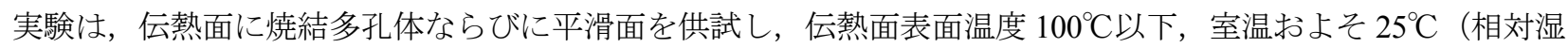
度 60\%）で，液滴体積およそ $8.8 \mu 1$ (等価直径で約 $2.56 \mathrm{~mm}$ ）の単一蒸留水滴を加熱面に滴下・衝突させ，液滴寿 命の測定，ビデオファイバースコープによる滴蒸発挙動の観察およびその録画画像による液滴形状の経時変化を 求めた。 さらに, 液滴の衝突時の瞬間的な動きを観察するために, 高速度ビデオカメラ（nac HSV-1000）を用い て撮影し，平滑面と焼結多孔体面との相違について調べた.

伝熱面に衝突させた液滴の形状や後述する焼結多孔体面だけに生ずる液体浸透の広がりの測定は, 伝熱面真上 に固定したビデオファイバースコープの録画映像から, 希望の蒸発時間の静止画をデジタル写真として保存する. これらをパーソナルコンピューターで, 液滴ならぬれ面積を, 浸透液体ならそのしみ込み部分の面積を解析して 求め, それぞれ等価直径に換算して実験值とした。 なお，高い衝突速度では液滴が分裂するが，この場合は処理 せず液滴寿命だけを測定した。

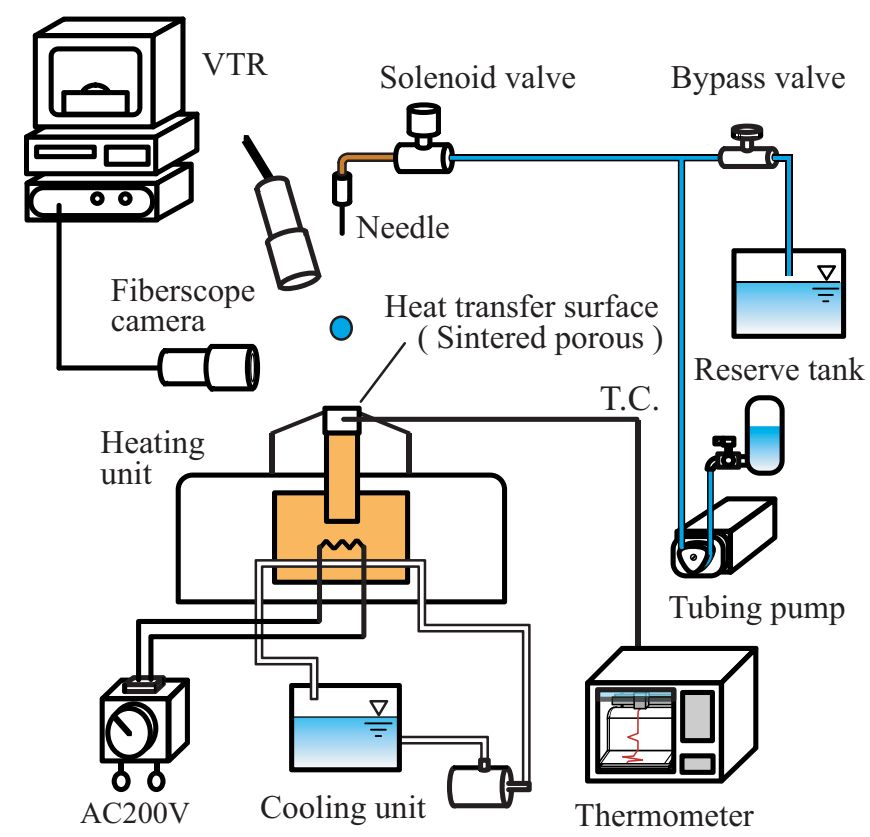

Fig. 2 Schematic diagram of experimental apparatus.

\section{5. 結果と考察}

\section{$5 \cdot 1$ 液滴の衝突・変形挙動}

加熱面上での単一付着液滴の寿命は, 熱・物質伝達条件および液滴体積一定であれば, その接触径の大きさに よって決まる. この接触径の大小に係る影響因子としては, 加熱面のぬれ性, 液体の種類, そして, 滴下寸る液 滴の衝突 $W e$ 数が関係する. 図 3 は高速ビデオカメラで撮影した, 液滴の衝突・変形過程の画像, および各ショ ットをスケッチ図で表したものである. 鏡面に研磨した平滑伝熱面に衝突した液滴は，ミリ秒で拡大，収縮，反 発の後, spherical cap と表現できる単一付着滴を, We 数が高い場合には, 数個に分裂した付着液滴群を形成し安 定化する. 以上が, 巨視的には平滑な固体面上での様相であるが, 焼結多孔体面では, 顕著な収縮は観察されず, わずかに液滴高さを増してから安定する（図 $3(b)$ ) .We 数がある值に達すると，付着滴は分裂あるいは破断し て, 液滴高さの低い薄膜を形成する. 一例として, 図 4 に We 数に対する付着滴の形状を示寸. 焼結多孔体面上 の付着安定した液滴は, 平滑面と比べて接触径が大きく, それゆえ, 高さの低い液滴を形成している. さらに, ぬれ縁の形状は平滑面上とは異なり不規則である. 

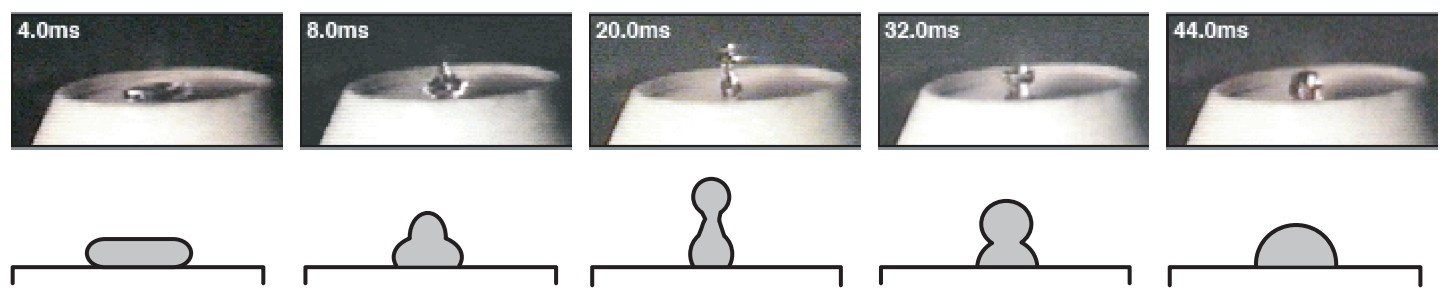

(a) Smooth surface
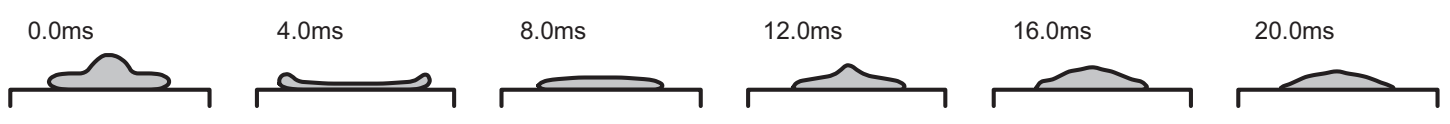

(b) Sintered porous surface

Fig. 3 Impaction behavior of water droplet on test surface: (a) $T_{\mathrm{w}}=80^{\circ} \mathrm{C}, W e=80$, (b) $\varepsilon=0.55, \delta=80 \mu \mathrm{m}, T_{\mathrm{w}}=62^{\circ} \mathrm{C}, W e=100$.

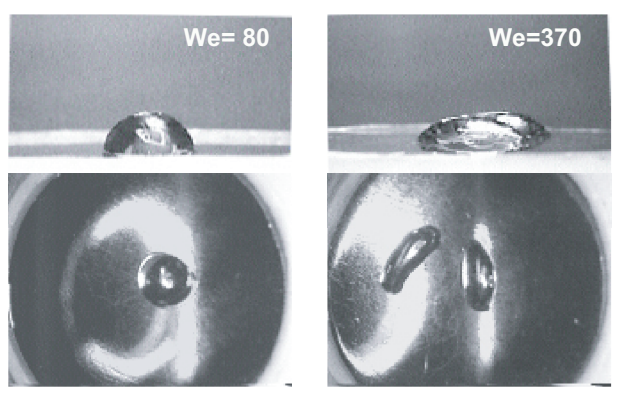

(a) Smooth surface
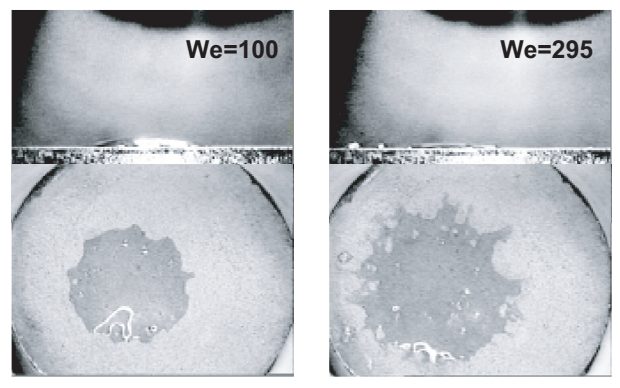

(b) Sintered porous surface

Fig.4 Profile shapes of liquid droplet on the heated surface: (a) $T_{\mathrm{w}}=80^{\circ} \mathrm{C}$, (b) $T_{\mathrm{w}}=53^{\circ} \mathrm{C}, \varepsilon=0.37, \delta=70 \mu \mathrm{m}$.

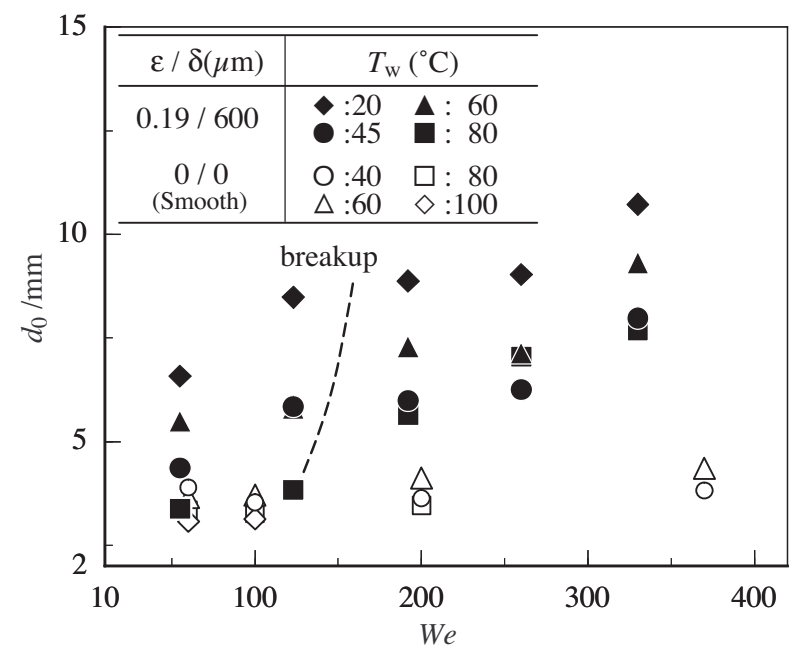

Fig.5 Comparison of diameter of deposited droplet on test surface just after impaction.

以上の観察から得られた, $W e$ 数に対する初期液滴径（初期接触径） $d_{0}$ ならびに付着滴の分裂限界について, 図 5，6 亿示す。ここで初期液滴径は，一連の衝突・変形挙動を終えた液滴が静的に付着し安定した状態におけ る接触直径である．まず，初期液滴径 $d_{0}$ については，白抜き記号で示寸平滑面の場合では $W e$ 数および表面温度 $T_{\mathrm{w}}$ と無関係にほぼ一定の大きさを保つのに対し, 多孔体面では, $W e$ 数の増加とともに大きくなる. 図中の破線 は, 多孔体面において観察実験で得られた分裂限界We 数を結んだ境界である. この限界については, 図 6 に示 すように, 平滑面では約 $80^{\circ} \mathrm{C}$ 超えてから強い温度依存性を示すのに対して, 多孔体面では限界 $W e$ 数が低く, 


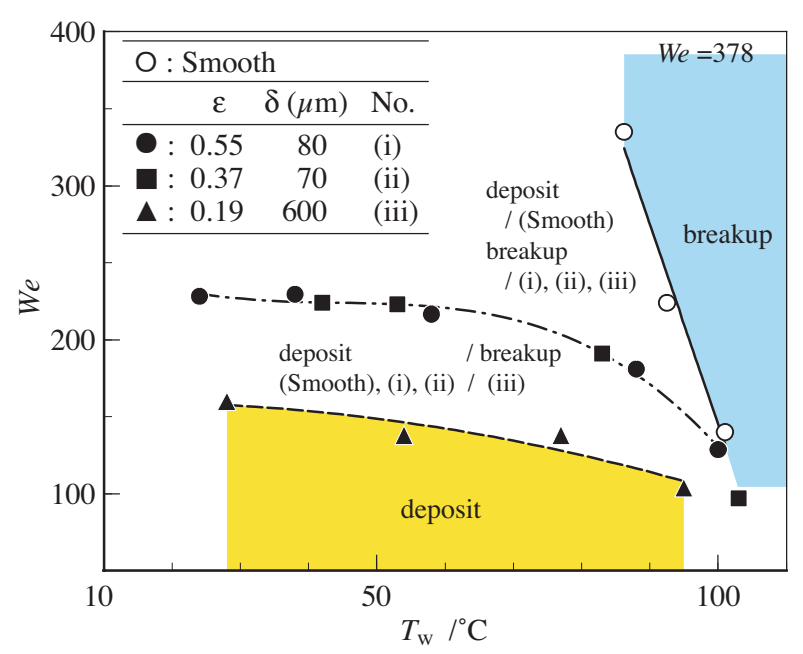

Fig.6 Breakup criteria of impacting water drop on test surface.

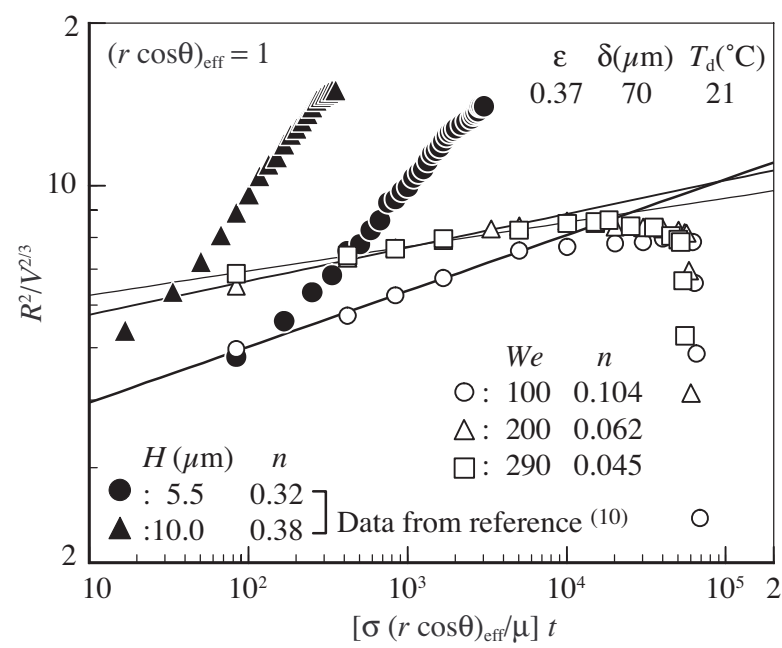

Fig.7 Comparison of spreading kinetics for water drop on non-heated test surface.

この限界值の加熱面温度に対する依存性が弱い, 特に, 気孔率 0.19 では, 限界 $W e$ 数が供試面中最も低いこと, および温度依存性がさらに小さい。

焼結多孔体面上に衝突付着したその後の動挙動について図 9 で説明する. 焼結多孔体面上に付着した液滴 は，分裂あるいは孤立状態に関わらず，ある焼結状態の多孔体面であれば，安定後 $\left(d_{0}\right)$ しばらくすると液 滴 $\left(d_{d}\right)$ の周囲に多孔体表面での毛管現象による液滴からの浸透液の広がり $\left(d_{p}\right)$ が観察される.この浸透 液の広がり速度は, 多孔体の焼結状態, 加熱表面温度および衝突液滴の $W e$ 数により変化することを実験的 に確認した.

\section{$5 \cdot 2$ 焼結多孔体面への液体浸透}

焼結多孔体面の浸透特性として, 気孔率 0.37 （焼結層厚さ $70 \mu \mathrm{m} ）$ ，室温環境下（ $1 \mathrm{~atm}, 21^{\circ} \mathrm{C}$ ）での浸透液径 $d_{p}$ の経時変化を図 7 に示す. 図 7 は, 実測した浸透液の広がりを面積で評価し液滴体積で無次元化した $R^{2} / V^{2 / 3} を$, 滴下した液滴の物性に微細構造（真の毛管半径 $r$ ）を含めて標準化した観測時間との関係 ${ }^{(11)}$ で表しており，さら に比較として超微細構造面の結果も合わせて示している. ここで, 無次元広がり面積は, 滴下される微細構造面 の液滴 1 個のしみ込み性能を, $\left[\sigma(r \cos \theta)_{e f f} \mu\right] t$ は浸透現象の経過を表す．まず，滴下直後からの液体浸透につい て多孔体面を例に説明する．図 7 では（蒸発）消滅までの実験点を示してある．浸透液の広がりは，その初期過 


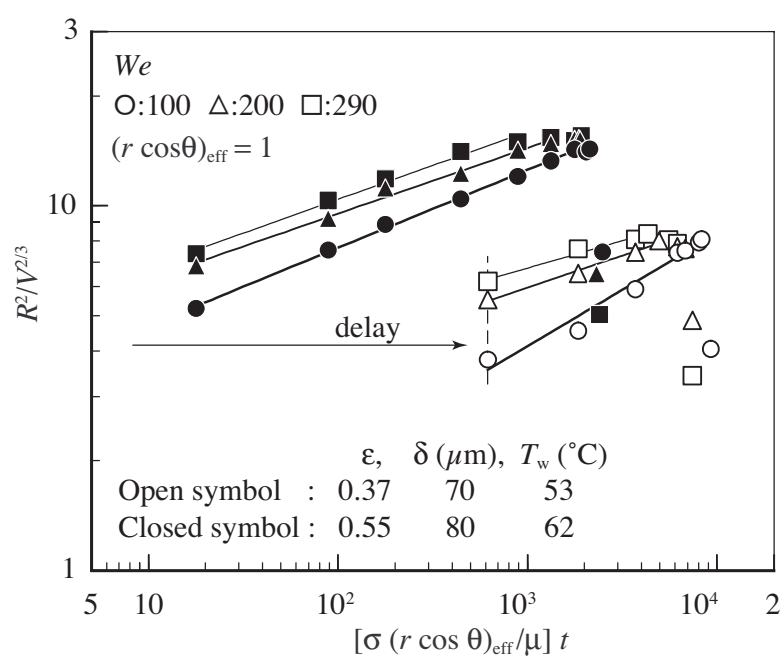

(a)

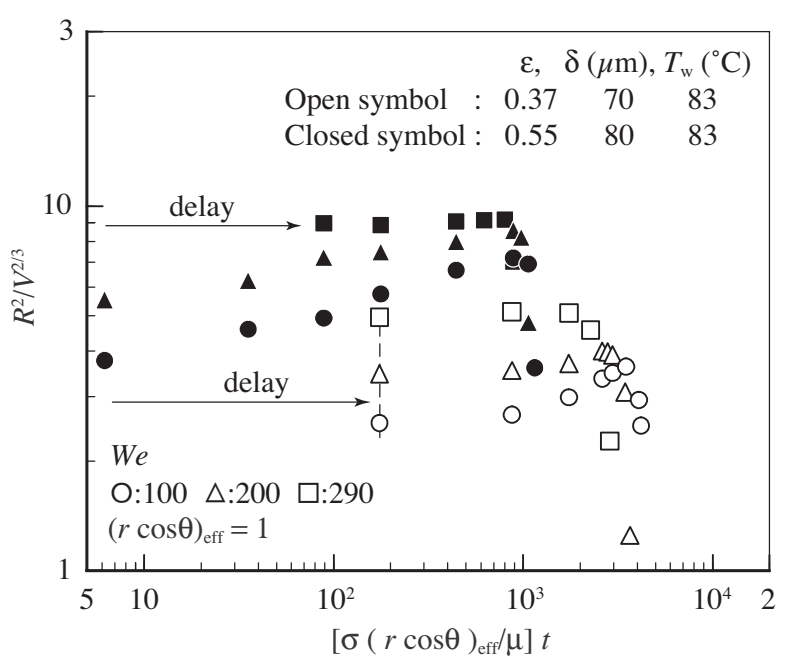

(b)

Fig. 8 Comparison of spreading kinetics of water drop on heated sintered-porous surface: (a) $T_{\mathrm{w}}=53 \sim 62^{\circ} \mathrm{C}$, (b) $T_{\mathrm{w}}=83^{\circ} \mathrm{C}$.

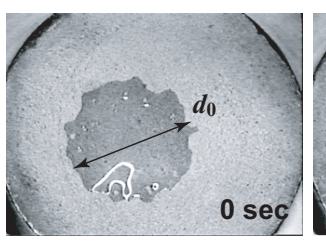

stage 1
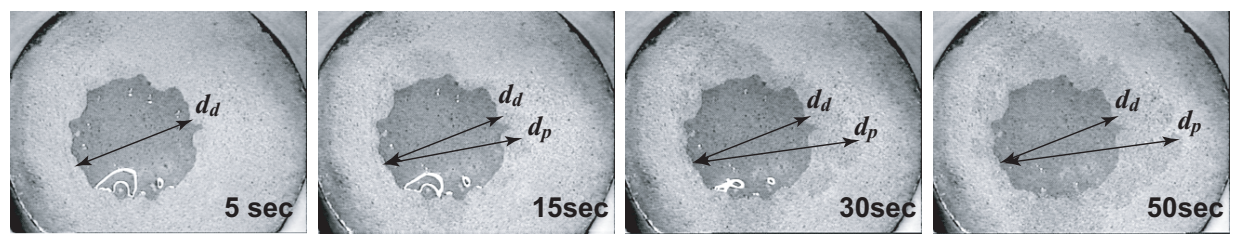

stage 2
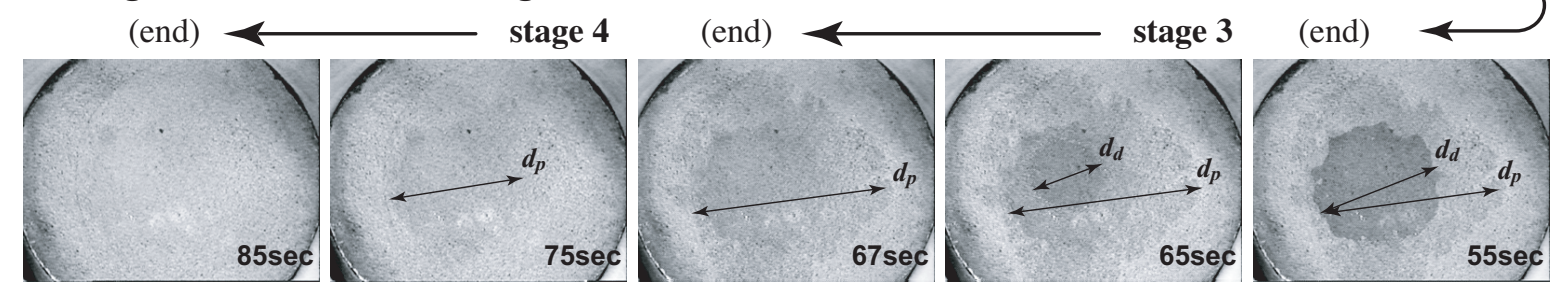

Fig.9 Top view of sintered porous surface during evaporation: $\varepsilon=0.37, T_{\mathrm{w}}=53^{\circ} \mathrm{C}, W e=100$.

程においてあるべき乗則にしたがって拡大する，その後，浸透速度は蒸発界面の増加とともに蒸発量が増すと減 速し, やがて, 液体浸透による付着滴の消滅で液の供給を失うと縮小して消滅する. 構造面の性能は, 浸透速度 の大きさを表すべき乗数 $n$ とその最大広がり径によって評価できる. 以上の理解のもと，本実験で供試した多孔 体面における全体的な特徵として, 心゙き乗数 $n$ は Washburn 則 $(n=0.5){ }^{(13)}$ より小さい, すなわち, これまで報告 されている種々の粗面 (7) (9) への浸透速度より遅い. 超微細構造面との差異として, 浸透速度は多孔体面のほうが 小さく, また, その広がり径も小さい. We 数の影響として, 浸透速度は $W e$ 数の増大とともに小さくなるが, 最 大到達浸透液径およびその到達時間に顕著な差は見られない.

次に, 浸透液の広がりにおよぼす加熱面温度 $T_{\mathrm{w}}$ の影響を図 8 に示寸. 図 8 (a)の表面温度 $T_{\mathrm{w}}=50 \sim 60^{\circ} \mathrm{C}$ の場合 には, 前述した特性を示している. 特に, 気孔率 0.55 では, 液の広がり開始が早いこと, 浸透速度が大きいこと, そして, 最大広がり径が大きく, またその到達時間も短いことがわかる．これらの特性はより高温になると（図 8 (b)），浸透速度はべき乗則にのらないこと，また，最大広がり径は We 数のより大きい条件でわずかに大きく なることがわかる.これらのことは, 液体が比較的高温の多孔層に浸透するとき, そのぬれ先端での蒸発量が増 し，見かけ上，浸透が停止あるいは減速するためと考えられる。 


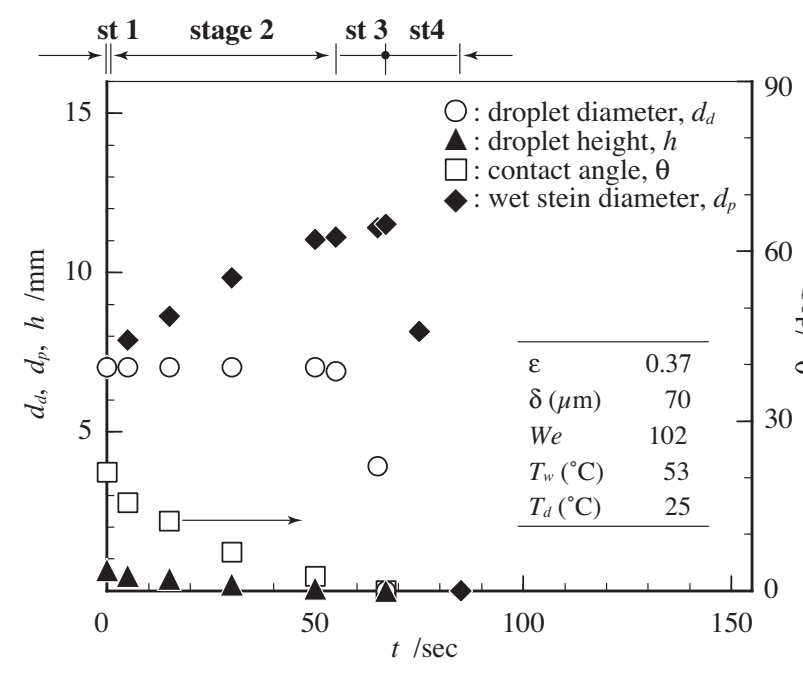

(a)

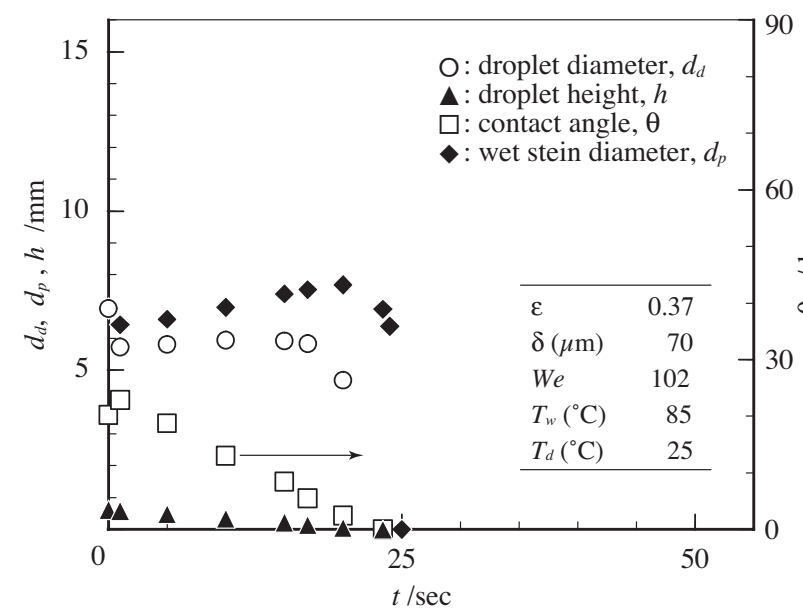

(c)

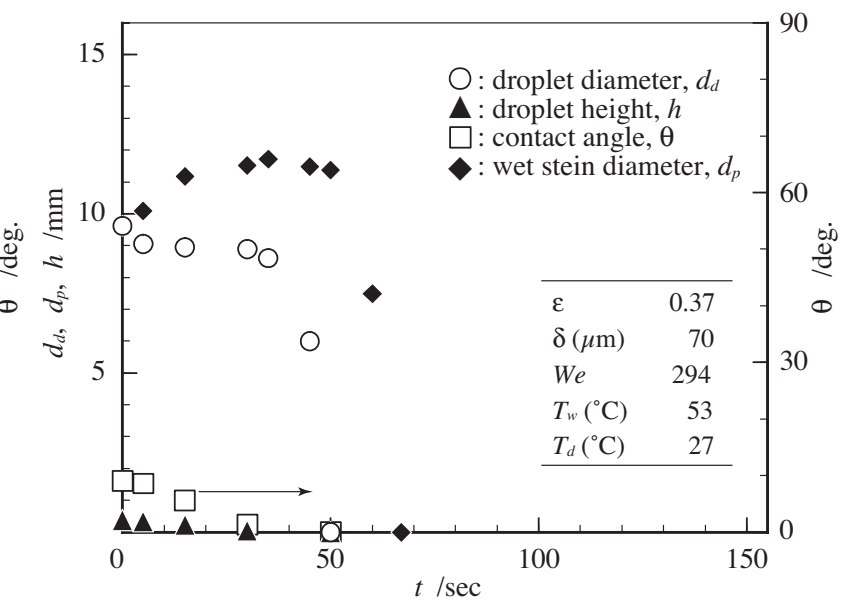

(b)

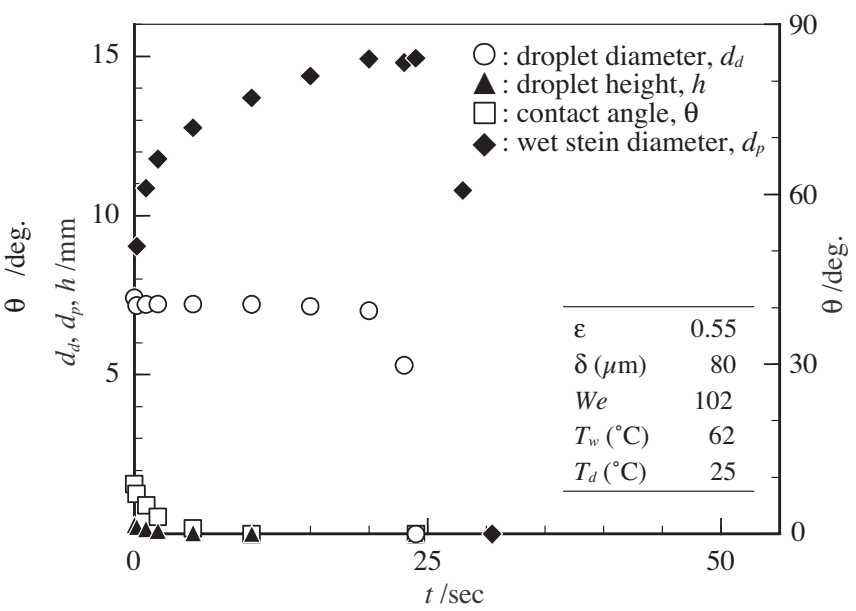

(d)

Fig. 10 Variation of droplet shape on sintered porous surface with time: (a) $\varepsilon=0.37, T_{\mathrm{w}}=53^{\circ} \mathrm{C}, W e=100, \quad$ (b) $\varepsilon=0.37, T_{\mathrm{w}}=53$ ${ }^{\circ} \mathrm{C}, W e=294,(\mathrm{c}) \varepsilon=0.37, T_{\mathrm{w}}=85^{\circ} \mathrm{C}, W e=102,(\mathrm{~d}) \varepsilon=0.55, T_{\mathrm{w}}=62^{\circ} \mathrm{C}, W e=102$.

\section{$5 \cdot 3$ 液滴形状の経時変化}

焼結多孔体面上での液滴蒸発における，浸透液および液滴形状の経時変化について図 9 に示す，液滴は，滴下 衝突後， 5.1 節に詳述した多孔体面特有の衝突変形挙動を呈して安定寸る（stage1）。次いで，液滴は，その一部 が開口気孔内部へ浸透するとともに，多孔層表面の毛管力によって広がる浸透液に囲まれるが，およそ接触径 $d_{d}$ 一定を保つ. このとき浸透液は, 加熱面温度 $T_{\mathrm{w}}$ と気孔率 $\varepsilon$ （層厚さ $\delta$ ）に応じた浸透速度で広がり続ける. 液滴 高さ $h($ 接触角 $\theta)$ は, 主に液体浸透と蒸発界面からの蒸発によって減少する（stage2）。液滴径 $d_{d}$ は, 液滴高さ $h$ (接触角 $\theta$ ) がある值に達すると, 液滴高さ $h$ （接触角 $\theta$ ) をほぼ一定に保ちながら急激に縮小消滅し, 浸透液 だけがぬれ滲みとして残る（stage3）。供給元を失った浸透液は，急激にその領域を小さくして消滅（蒸発）す る（stage4）。

以上の多孔体面上での液滴蒸発の経時変化を図 10 に示す. 加熱面温度一定のもと We 数の増大は初期液滴径が 大きくなるため浸透速度は遅い（図 $10(\mathrm{~b})$ ) 。しかし, 液滴形状については, 液滴高さ $h$ が低い（接触角 $\theta$ 小さ い)ことを除けば大きな差異はない. 加熱面温度 $T_{\mathrm{w}}$ の増加は, 蒸発量が増加するため stage4 の存在時間が短くな る（図 10 (c)）。気孔率の影響として, 気孔率 0.55 では, 浸透液の速度およびその最大広がり径が大きいため, 蒸発消滅までの期間は短いが，液滴形状についての差異はない（図 $10(\mathrm{~d})$ )。 


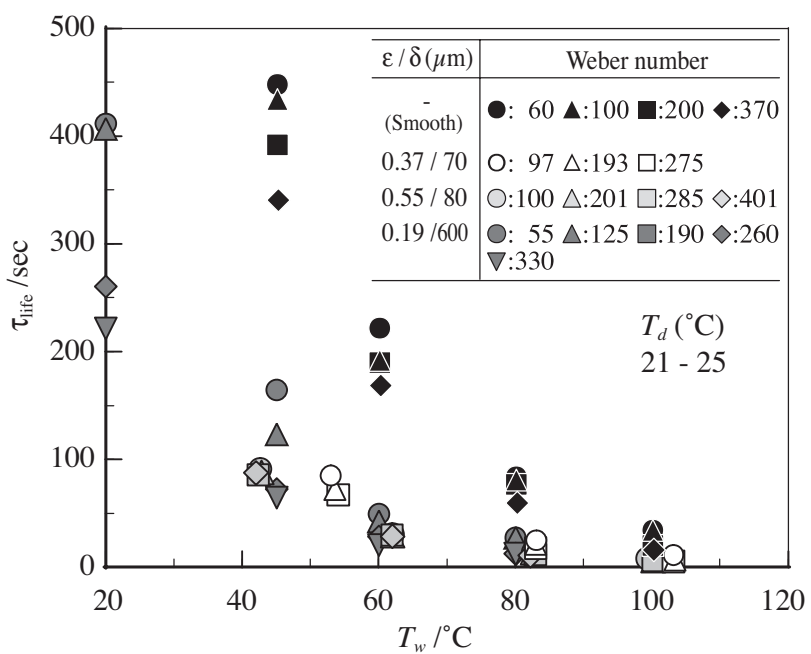

Fig.11 Variation of droplet lifetime on heated surface with heated surface temperature.

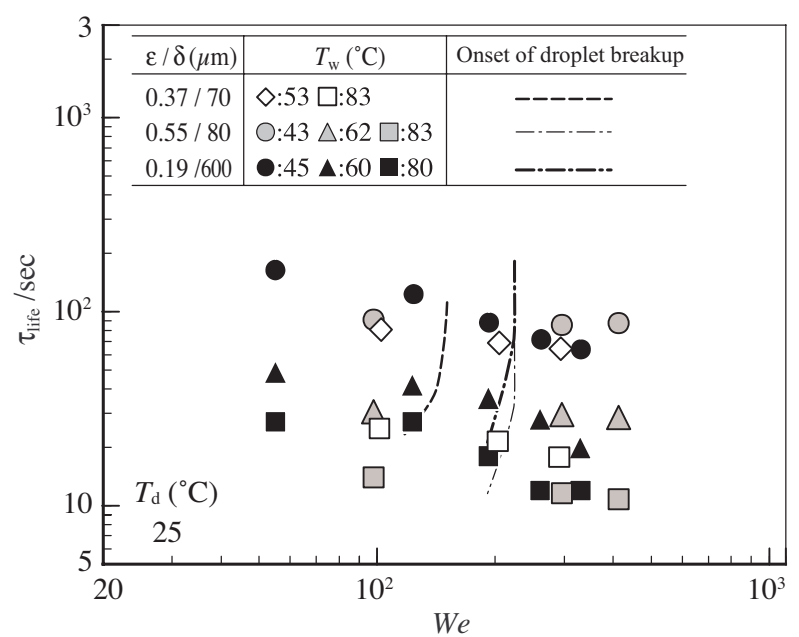

Fig.12 Variation of droplet lifetime on sintered porous surface with Weber number.

\section{$5 \cdot 4$ 液滴寿命}

焼結多孔体の伝熱促進効果について，同一体積の液滴に対する伝熱面上での消滅時間，すなわち，液滴寿命を 図 11 に示す.これより,伝熱面温度が飽和温度以下における液滴蒸発において, 焼結多孔体面上での液滴寿命は, その表面の微細構造によって（1）接触径が Wenzel の取り扱いで説明されるとおり大きくなること，また，多 孔層に浸透した液が好広がる場合には，（2）全蒸発界面が増加することにより，平滑面と比べ短くなる．実 験結果では，特に加熱面温度 $60^{\circ} \mathrm{C}$ 以下の蒸発量の少ない温度域でより顕著である. 多孔体面での比較において, 加熱面温度 $40^{\circ} \mathrm{C}$ 付近に着目すると, 気孔率 0.19 では, $W e$ 数が小さい場合に $(W e=55)$ 寿命が長く, $W e$ 数の増 加とともに，気孔率 $0.37 ， 0.55$ とほぼ同じ程度となる。この点について，液滴寿命におよぼす $W e$ 数の関係で説 明する。

図 12 に液滴寿命と $W e$ 数との関係を示す. 図 12 中の破線および一点鎖線は, 各多孔体面での分裂限界を表す. まず，浸透液の広がらない気孔率 0.19 において，液滴寿命は，接触径が $W e$ 数とともに増加するため, $W e$ 数の 増大とともに短くなる.特に, 液滴の分裂後（同図中の破線）においてより顕著である.この分裂後については, 衝突によって広範囲に分裂した液滴が直ちにその付着面で内部に浸透・蒸発し，衝突のよどみ点に存在する液膜 量が減少したためである。これに対し, 浸透液が広がる多孔体面では, これの拡大による蒸発界面の増大によっ て, We 数依存（初期接触径の依存）が小さい. より詳細には，気孔率 0.37 では，浸透液の最大広がり径が小さ くまた到達時間も長いため, 初期液滴径の差がほぼ全ての stage において生じ, これにより We 数に対する依存性 をわずかに示す．他方，これとは逆の気孔率 0.55 では，蒸発に有利な浸透液界面が大きいため，初期液滴径の差 


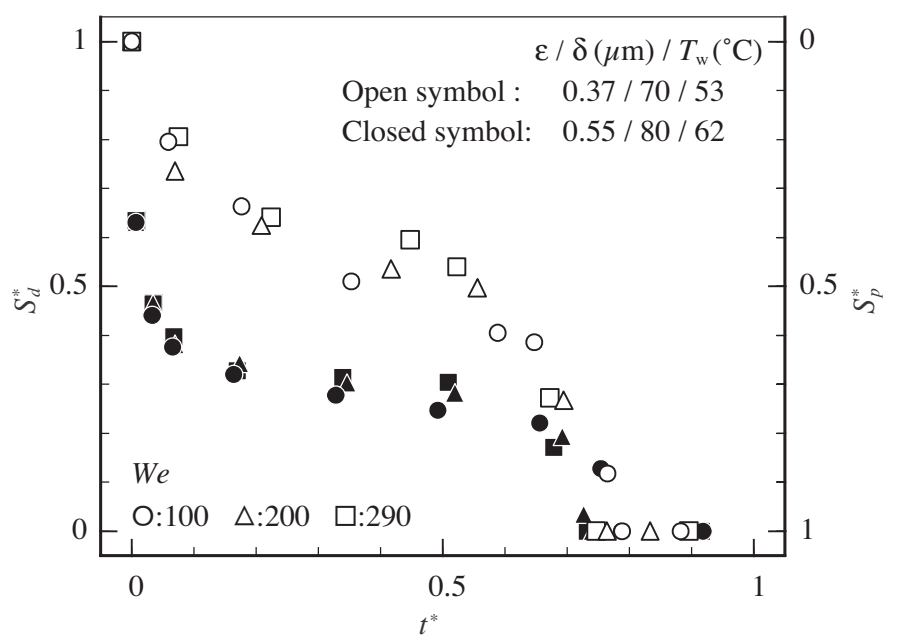

Fig.13 Variation of ratio of droplet surface area to overall evaporating area with non-dimensional time.

が相対的に小さくなる.このことは, 図 13 に示した全蒸発界面積 $S$ に占める液滴界面割合の経時変化からも明ら かで，気孔率 0.37 では，液滴寿命の約半分の期間を液滴界面が蒸発界面の約 5 割占めるのに対し，気孔率 0.55 では，浸透液界面が約 7 割占める。.さらに，この多孔体面では，気孔率が大きいことから多孔層内部への浸透量 も多いと考えられ，その結果，顕著な差が現れなかったと言える.

\section{6. 結}

ミスト冷却熱伝達の高性能伝熱面の探索を目的に, 純銅粉末を SPS 法により焼結接合することで比較的容易に 作製可能な焼結多孔体面を提案し，その伝熱促進効果について実験的に追究を行い，以下の結論を得た.

（1）焼結多孔体面上の液滴は, 開口気孔などの影響により平滑面に比べ液体との接触角が小さくなるため, 同一液量に対して接触径が大きく高さの低い液滴を形成する.

（2）蒸発促進効果となる付着液滴の液滴浸透は，多孔層の気孔率に依存する．液滴浸透を生ずる場合では, 気孔率が大きいものほどその速度は速く，その最大広がり径も大きい.

（3）焼結多孔体面上の液滴の寿命は平滑面に比べて短く，特に伝熱面温度が低いほど蒸発促進効果は顕著で ある。

（4）液滴浸透が生じない多孔体面では, We 数の増加による付着液滴の分裂によって液滴寿命は短くなる. 他方, 液滴浸透を生ずる場合では, 浸透液の拡大によって, 衝突でもたらされる液滴挙動に因らず, 蒸 発界面が形成するため, $W e$ 数の依存性は小さい.

\section{文献}

(1) Pautsch, A. G., and Shedd, T. A., "Spray impingement cooling with single- and multiple-nozzle arrays. Part I: Heat transfer data using FC-72", International Journal of Heat and Mass Transfer, Vol.48 (2005), pp.3167-3175.

(2) Hsieh, C. -C., and Yao, S. -C., "Evaporative heat transfer characteristics of a water spray on micro-structured silicon surfaces", International Journal of Heat and Mass Transfer, Vol.49 (2006), pp.962-974.

（3）マイクロ・ナノ熱流体ハンドブック編集委員会, マイクロ・ナノ熱流体ハンドブック（2006）p.303, エヌ・ティー・ エス.

(4) Silk, E. A., Kim, J., and Kiger, K., "Spray cooling of enhanced surfaces: Impact of structured surface geometry and spray axis inclination", International Journal of Heat and Mass Transfer, Vol.49 (2006), pp.4910-4920.

(5) Sodtke, C., and Stephan, P., "Spray cooling on micro structured surfaces", International Journal of Heat and Mass Transfer, Vol.50 (2007), pp.4089-4097. 
(6) Shen, J., Graber, C., Liburdy, J., Pence, D., and Narayanan, V., "Simultaneous droplet impingement dynamics and heat transfer on nano-structured surface”, Experimental Thermal and Fluid Science, Vol.34 (2010), pp.496-503.

(7) Apel-Paz, M., and Marmur, A., "Spreading of liquids on rough surfaces", Colloids and Surfaces A: Physicochemical and Engineering Aspects, Vol.146 (1999), pp.273-279.

(8) Bico, J., Tordeux, C., and Quéré, D., “Rough wetting”, Europhysics Letters, Vol.55, (2001), pp.214-220.

(9) Ishino, C., Reyssat, M., Reyssat, E., Okumura, K., and Quéré, D., "Wicking within forests of micropillars”, Europhysics Letters, Vol.79 (2007), 56005.

(10) 瀧本昭, 松川昌史，小坂暁夫，“ミスト泠却における超微細構造面の蒸発促進効果（単一液滴による実験）”，日本 機械学会論文集 B 編, Vol. 67, No.658 (2001), pp. 1445-1450.

(11) 小坂暁夫, 瀧本昭, “ミスト冷却における超微細構造面の蒸発促進効果（液体浸透を考慮した液滴蒸発過程のモデ ル化による蒸発解析）”，日本機械学会論文集 B 編, Vol. 74, No.745 (2008), pp. 1991-1998.

(12) Maxwell, J.C., A treatise on electricity and magnetism, Vol.1, 3rd ed. (1904), p.440, Oxford: Clarendon Press.

(13) Washburn, E. W., “The Dynamics of Capillary Flow”, Physical Review, Vol.17 (1921), pp.273-283. 